\title{
Net Foreign Asset Positions and Appreciation Expectations on the Swiss Franc and the Japanese Yen
}

\author{
Sophia Latsos \\ Gunther Schnabl
}

\author{
CESIFO WORKING PAPER NO. 5490 \\ CATEGORY 7: MONETARY POLICY AND INTERNATIONAL FINANCE \\ August 2015
}

An electronic version of the paper may be downloaded

- from the SSRN website:

- from the RePEc website:

www.SSRN.com

- from the CESifo website:

www.RePEc.org

www.CESifo-group.org/wp 


\title{
Net Foreign Asset Positions and Appreciation Expectations on the Swiss Franc and the Japanese Yen
}

\begin{abstract}
The paper shows that currencies of countries with persistent current account surpluses and high foreign-currency denominated assets, such as the Swiss franc and the Japanese yen, are under persistent appreciation pressure, particularly when the centres of the world monetary system follow expansionary monetary policies. This limits the choice of exchange rate regime. Given flexible exchange rates, a negative risk premium on the domestic interest rate can emerge. Empirical estimations provide mixed evidence for a negative impact of net foreign asset positions and exchange rate uncertainty on interest rates of international creditor countries at the periphery of the world monetary system.
\end{abstract}

JEL-Code: F150, F310, F330.

Keywords: Swiss franc, Japanese yen, exchange rate risk, negative risk premium, self-fulfilling expectations, appreciation pressure.

Sophia Latsos

University of Leipzig

Institute for Economic Policy

Grimmaische Str. 12

Germany - 04109 Leipzig

latsos@wifa.uni-leipzig.de
Gunther Schnabl

University of Leipzig

Institute for Economic Policy

Grimmaische Str. 12

Germany - 04109 Leipzig

schnabl@wifa.uni-leipzig.de 


\section{Introduction}

In January 2015 the Swiss National Bank announced to float the exchange rate of the Swiss franc after it had been pegged tightly to the euro since September 2011. The president of the Swiss National Bank stressed that in the future the Swiss National Bank would conduct the monetary and currency policy of the country as an independent central bank. The announcement triggered a run into the Swiss currency, which led to a sudden appreciation of the franc versus the euro of up to $30 \%$. Since then, the Swiss National Bank seems to have resumed (discretionary) foreign exchange intervention, having accumulated foreign reserves equivalent to 90 billion euros in the first quarter 2015. This may suggest that the Swiss National Bank has returned to a non-announced exchange rate target of above 1.0 Swiss franc per euro (see Figure 1).

\section{Figure 1: Exchange Rate of the Swiss Franc against the Euro (Daily Data)}

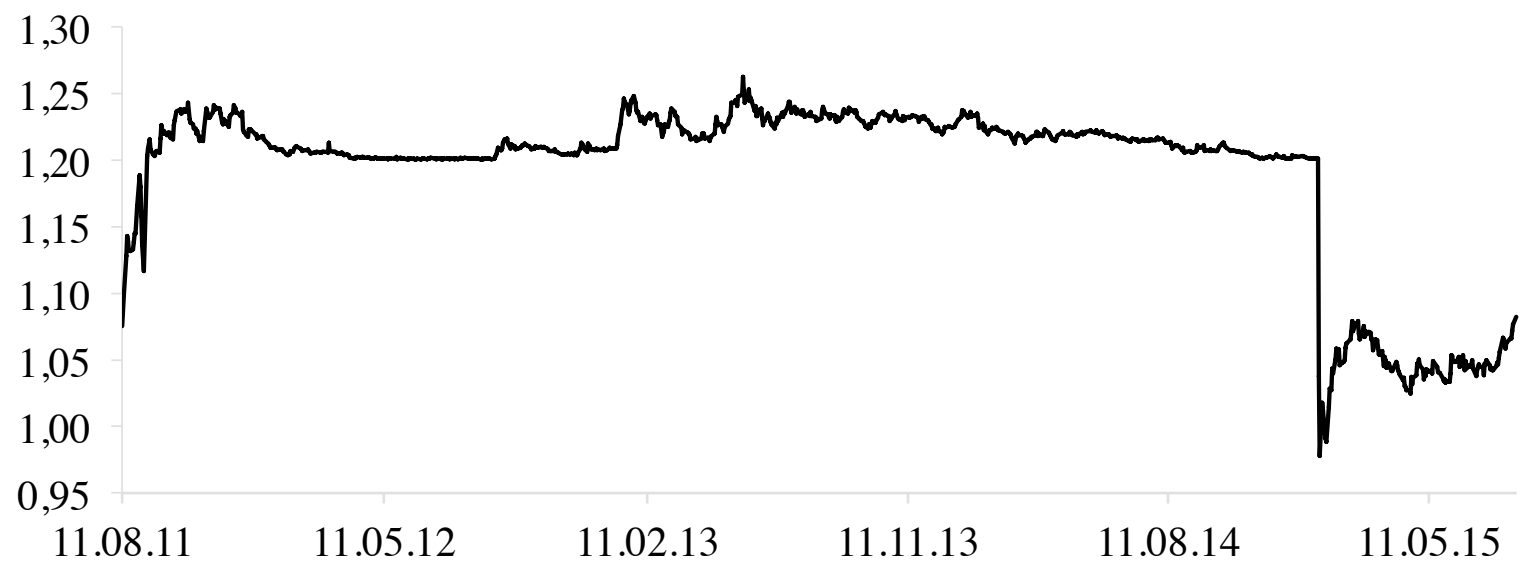

Source: Pacific Exchange Rate Service.

Recent academic research on the Swiss exchange rate policy is rare. Policy recommendations have either focused on the benefits of monetary policy independence, or have stressed the negative impact of appreciation on Swiss export industries (see Bernholz and Minsch 2015). A study by Abrahamsen and Simmons-Süer (2011) reveals high exchange rate elasticities of real exports in the tourism sector and selected manufacturing industries. Putting (expected) exchange rate movements into the context of international portfolio allocation and uncovered interest rate parity Kugler and Weder (2004) find for the period from 1980 - 1998 that mean returns on Swiss assets 
have been significantly smaller than for other currencies. They associate this "return anomaly" with an insurance premium against rare global catastrophic events. ${ }^{1}$

From a broader perspective exchange rate fluctuations have also revaluations effects in the financial sector in the face of foreign-currency denominated assets (McKinnon and Schnabl 2004b), which can undermine financial stability. This effect may become stronger in a world where external wealth positions are continuing to grow (Lane and Milesi-Ferretti 2007) and where an increasing number of countries are running net foreign asset positions (Bénétrix et al. 2014).

Building upon Goyal and McKinnon (2003) as well as Lane and Milesi-Feretti (2001) we identify common characteristics for the Swiss franc and the Japanese yen with respect to persistent appreciation pressure and a downward pressure on domestic interest rates. A theoretical link between the net international investment position, exchange rate movements and nominal interest rate differentials is established. Fixed effect panel estimations provide mixed evidence for a negative impact of net international investment positions and exchange rate uncertainty on interest rates of creditor countries at the periphery of the European monetary system.

\section{The Theory of the Negative Interest Rate Premium}

The open interest rate parity condition assumes perfect arbitrage in international capital markets. For instance, a Swiss (Japanese) investor can place one unit of saving either at home for the interest rate $\mathrm{i}_{\mathrm{CH}}\left(\mathrm{i}_{\mathrm{Jap}}\right)$ or in foreign for the interest rate $\mathrm{i}_{\mathrm{EA}}\left(\mathrm{i}_{\mathrm{US}}\right) .^{2}$ We assume for simplicity that a Swiss investor will only invest in the euro area at the interest rate $\mathrm{i}_{\mathrm{EA}}$ (a Japanese investor will only invest in the United States at the interest rate ius). ${ }^{3}$ We stress that Switzerland - like Japan - is in net terms an international

1 Kugler and Weder (2009) reconsider this effect.

2 Investing in time $t$ one unit of saving in home has a return of $1+\mathrm{i}_{\mathrm{CH}}\left(1+\mathrm{i}_{\mathrm{Jap}}\right)$ after the end of the investment period in $t+1$. For one unit invested in the euro area, the return in domestic currency at the end of the investment period is $\left.\left(\left(1+\mathrm{i}_{\mathrm{EA}(\mathrm{US})}\right) / \mathrm{e}_{\mathrm{t}}\right) * \mathrm{e}_{\mathrm{t}+1}\right)$ with e being the exchange rate between the Swiss franc and the euro (between the Japanese yen and the US dollar) in price notation.

3 This assumption corresponds to the regional currency habitat in the world economy. Whereas in Europe (and some neighbouring countries) the euro is the dominating international medium of exchange, unit of account, store of value, anchor currency, intervention currency and reserve currency, the dollar is the dominating international currency in the rest of the world (McKinnon 2013). 
creditor rather than a net debtor country (which may be suggested by its safe haven function in the international capital markets).

\subsection{The Uncovered Interest Rate Condition in Japan and Switzerland}

Assuming perfect arbitrage, equal country risk, zero transaction costs and adjusting for exchange rate changes the return at the end of the investment period is equal for domestic and foreign investment, even in the case of unhedged investment in foreign capital markets. ${ }^{4} \mathrm{~A}$ higher (lower) return of foreign investment is compensated by the depreciation (appreciation) of the domestic currency versus the investment currency:

$i_{j}-i_{k}=E\left(\widehat{e_{h l}}\right)$

In equation (1) the term $i_{j}$ indicates the interest rate of the creditor country $j$ (here Switzerland and Japan), $\mathrm{i}_{\mathrm{k}}$ indicates the interest rate of the debtor economy (here Germany/euro area ${ }^{5}$ and US). The term $h$ represents the currency of the creditor country, the term 1 the currency of the debtor country. The term $E\left(\hat{e}_{h l}\right)$ marks the expected percent exchange rate change between Swiss franc and euro (Deutsche Mark) or yen and dollar in price notation. Positive values indicate depreciation, negative values appreciation.

The interest rate differentials between Switzerland and the euro area (Germany before 1999) as well as between Japan and US (left hand part of equation (1)) are shown in Figure 1. For both country pairs we observe long-term downward trends in interest rates. Switzerland and Japan have mostly lower short-term and long-term interest rates than the large anchor countries Germany/euro area and US. Open interest rate parity as in equation (1) would suggest that the Japanese yen has been continuing to appreciate against the dollar and the Swiss franc against the euro (before 1999 the German mark). From a long-term perspective, Figure 2 by and large confirms this. Both the Japanese yen and the Swiss franc have appreciated since January 1980 by about $50 \%$ against the

4 The equilibrium condition for the Swiss investor is $\left.1+i_{C H}=\left(\left(1+i_{E A}\right) / e_{t}\right)^{*} e_{t+1}\right)$ which is equivalent to the uncovered interest rate parity as in equation (1). Empirical evidence on the uncovered interest rate parity is mixed (see for instance Wu and Chen 1998, Chin 2005, Lothian and Wu 2011).

5 Germany (euro area) is assumed to be a net debtor country versus Switzerland and in absolute terms a larger net creditor country versus the rest of the world. That implies an overall international creditor position for Germany (euro area). 
dollar and euro (German mark), respectively. This corresponds to an average appreciation of $2 \%$ per year. ${ }^{6}$ Nevertheless, from a year-to-year perspective significant departures from the open interest rate parity can be observed, as in some periods negative interest rate differentials are paired with depreciation versus the anchor currency. In addition, the interest rate differentials are in average larger than the average appreciation (see Table 2 in section 3).

Figure 1: Long-term and Short-term Interest Rate Trends Japan/US and Switzerland/Germany/Euro Area
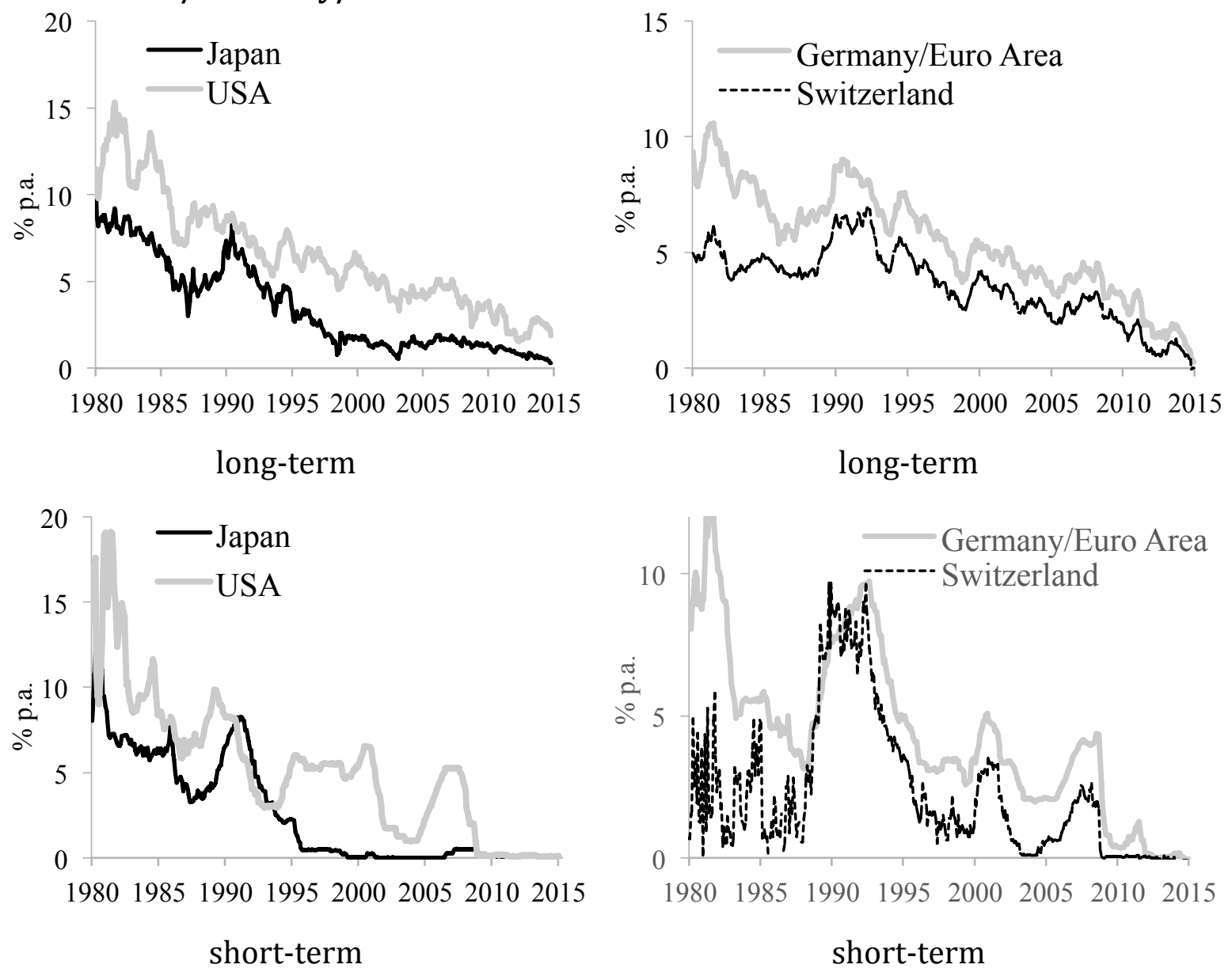

Source: IMF. Long-term is approximated by 10 -year government bonds yields, shortterm is approximated by money market rates.

\subsection{Net Foreign Assets and the Negative Risk Premium}

To provide a possible explanation for this "interest puzzle", we build upon Goyal and McKinnon (2003) and extend the open interest rate condition by an interest rate

6 In Japan, this trend halted with the introduction of Abenomics, starting from January 2013. 
premium $\varphi$, which reflects the exchange rate risk in countries with floating exchange rates. Since the collapse of the Bretton-Woods-System in the early 1970s the Japanese yen is floating - more or less - freely against the dollar (Figure 2). ${ }^{7}$ Also the exchange rate of the Swiss franc has been mainly floating against the German mark and since January 1999 against the euro. ${ }^{8}$ Only from December 2011 up to January 2015 a publicly announced lower boundary of the Swiss franc against the euro (1.2 Swiss franc per euro) was defended by the Swiss National Bank to prevent further appreciation.

\section{Figure 2: Exchange Rates Yen/Dollar und Swiss Franc/Euro/German Mark}
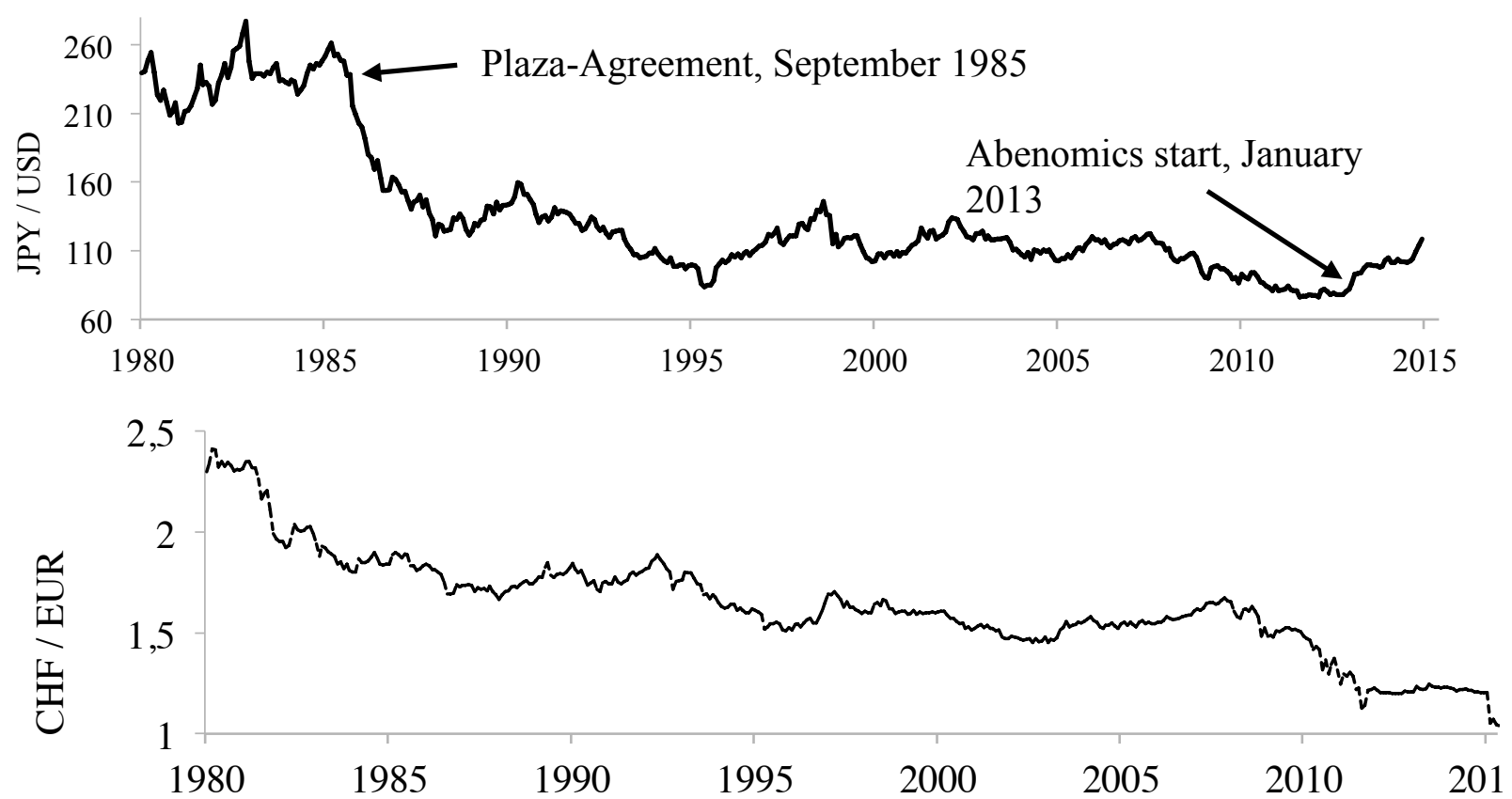

Source: IMF.

Exchange rate fluctuations cause two types of risk. First, if trade is invoiced in foreign currency, export-oriented enterprises face uncertainty concerning future profits in terms of domestic currency. If the currency appreciates, real exports and/or profit margins tend to decline. Second, if international assets and liabilities are denominated in foreign (instead of domestic) currency, individual international debtors and creditors face a currency mismatch and currency risk. The domestic-currency return of investment in foreign currencies strongly hinges on exchange rate changes during the

7 For details see McKinnon and Ohno (1997) as well as Danne and Schnabl (2008).

8 For a historical overview of exchange rate policies including Switzerland and Japan see Bordo, Humpage and Schwartz (2012). 
investment period as modelled by the open interest rate parity (see also footnote 2). In case of Switzerland and Japan a higher interest in Germany/euro area and US may be overcompensated by the appreciation of the domestic currency, turning the return of investment ex post negative.

The type of risk generated by exchange rate changes hinges inter alia on the sign of the net international investment position. The current account positions and the net international investment positions (NIIP) ${ }^{9}$ interact, in particular when trends in current account positions persist. As current account surpluses are equivalent to net capital exports, net international investment positions can be seen as a function of past accumulated net capital exports. ${ }^{10}$ Both Japan and Switzerland have realized current account surpluses since the early 1980s as shown in the left hand panel of Figure 3.11 This has been the source of growing positive net international investment positions as shown in the right hand panel of Figure $3 .^{12}$

In countries with underdeveloped capital markets, such as China, international assets are denominated in foreign currency because highly fragmented domestic capital markets do not offer sufficient investment opportunities (McKinnon and Schnabl 2009). Tight regulation of the domestic capital market and international capital controls deter foreign private investors. As highly regulated and fragmented capital markets cannot provide financial intermediation for high saving surpluses $(S-I=C A>0)$, foreign exchange intervention has to provide a substitute. The upshot is that a large share of international assets is held by the central bank in foreign currency. Even in countries with highly developed capital markets, such as Japan and Switzerland, investment in foreign capital markets is strongly tilted towards foreign-currency lending as the very large euro- and

9 Given a starting point in year 1, the net foreign asset position in year $\mathrm{n}$ is equivalent to the accumulated current account positions up to the year n: $N I I P_{n}=\sum_{s=1}^{n} C A_{s}$

10 In this context, Lane and Milesi-Ferretti (2005) stress that revaluation effects also matter. The change in the net international investment position NIIP is equivalent to the current account $\left(\mathrm{CA}_{t}\right)$ and revaluation effects $R V_{\mathrm{t}}: N I I P_{t}-N I I P_{t-1}=C A_{t}+R V_{t}$. Revaluation effects can originate in changes in foreign asset prices and exchange rate changes.

11 Note that in Japan, following the 2011 tsunami disaster, current account surpluses have declined as energy imports have increased.

12 This analysis focuses on aggregated net international investment positions. Joyce (2015) takes a closer look on the compositions of net international investment positions disentangling the asset and liability side as well as different forms of international assets such as FDI. 
dollar-based capital markets offer more attractive investment opportunities and lower transaction costs. ${ }^{13}$

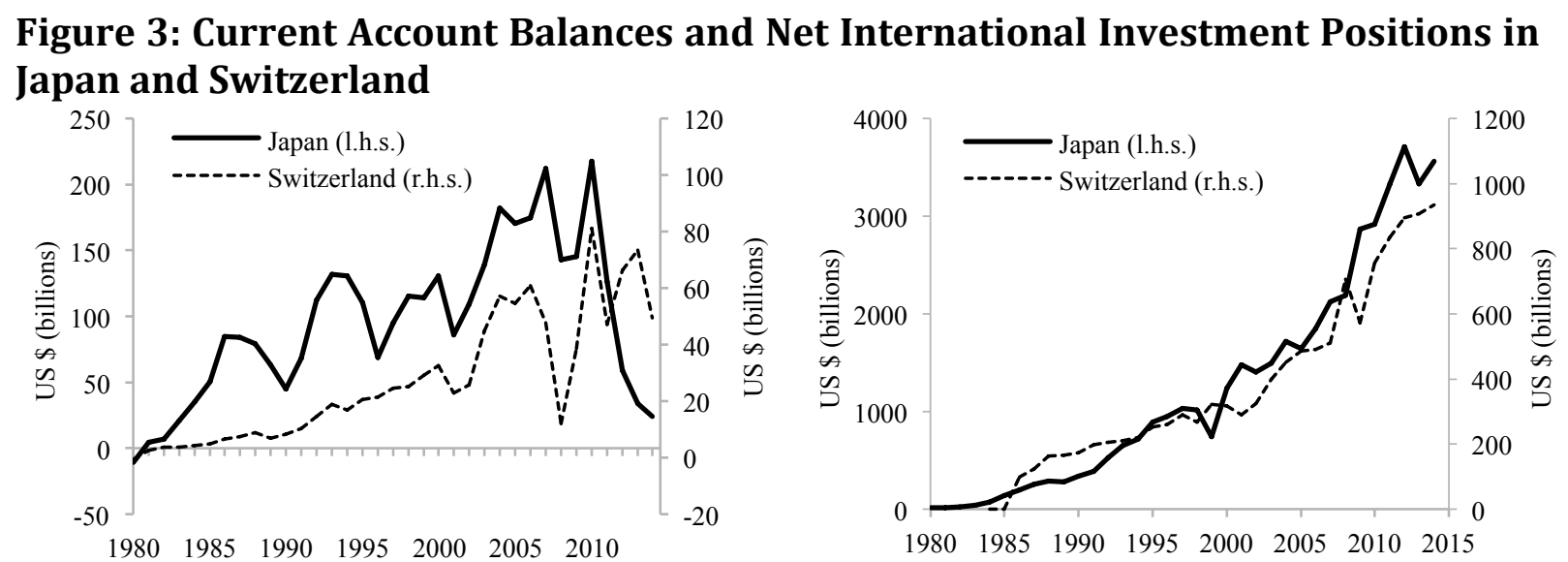

Source: IMF.

In the augmented open interest rate parity condition, the exchange rate risk in case of international creditor and debtor relationships can be modelled by the risk premium $\varphi$. It is defined as the excess yield, which domestic or foreign creditors demand for facing exchange rate risk. Given the fact that current account balances in the many countries have been following persistent trends (Lane and Milesi-Ferretti 2007), a systematic relationship between rising net foreign asset positions and exchange rate risk in form of a risk premium is assumed.

The risk premium is assumed to be positive for debtor countries with foreign debt denominated in foreign currency (McKinnon and Schnabl 2004a). Given that the foreign interest rate is exogenous domestic investors have to pay a mark-up on domestic interest rates to compensate foreign investors for default risk. In case of depreciation, foreign-currency denominated debt is inflated in terms of domestic currency, which tends to render the domestic debtors bankrupt. That was, for instance, the case in the wake of the Asian crisis (Corsetti et al. 1999).

13 Brown, Peter and Wehrmüller (2009) provide a detailed overview of the currency composition of Swiss international assets. Since the turn of the millennium Swiss and Austrian banks (by borrowing from Swiss banks) have issued substantial amounts of Swiss franc credit in many central and eastern European economies as well as in Germany (mainly held by local public entities). By Swiss franc lending the Swiss and Austrian banks could circumvent the exchange rate risk of international lending. The Swiss franc appreciation shock in early 2015 revealed, however, that this type of lending transforms currency risk into default risk (McKinnon und Schnabl 2004a,b). In case of a strong appreciation of the creditor currency the credit taking households, enterprises and local public entities are threatened by default. In some central and eastern European countries policy makers have shifted the costs of the revaluation effects of the franc appreciation back to banks. 
In case of foreign-currency denominated assets the risk premium on domestic interest rates is negative because an appreciation of the domestic currency reduces the value of foreign assets in terms of domestic currency (Goyal and McKinon 2003, McKinnon and Schnabl 2004b). ${ }^{14}$ For instance, Japanese investors, who invest their savings in dollars, realize losses in the face of lasting yen appreciation. The higher the foreign-currency denominated assets, the higher is the potential appreciation pressure on the domestic currency for the case when foreign assets are repatriated.

There are two side conditions. First, the risk premium is only demanded by private investors. Public investors are likely to subordinate returns on investment to other goals such as stable exports (i.e. employment) and financial stability. In export-dependent countries with large or fragile financial sectors such as Japan, China and Switzerland monetary authorities have made substantial efforts to prevent the domestic currencies from appreciating. ${ }^{15}$ Second, the size of domestic assets matters (Lane and MilesiFerretti 2005). If, as was the case in Japan in the second half of the 1980s and currently is the case in Switzerland, the value of the domestic assets is rising fast, the balance sheet risk for domestic households and financial institutions is softened. If, however, as was the case in Japan after the bursting of the bubble economy, domestic asset prices are falling, private investors get more vulnerable to devaluations of foreign assets.

To compensate for this foreign exchange risk, German/euro area (US) debtors have to pay a mark-up on the interest rate to Swiss (Japanese) investors. Assuming that US and euro area interest rates are given (because the US and the euro area have the largest capital markets and Japan / Switzerland are only one of many investors in US / euro area), the Japanese and Swiss interest rates have to be lower to increase the incentive for private investors for holding risky foreign currency assets. ${ }^{16}$ This implies a negative

14 This situation is coined "Conflicted Virtue“, as a complementary expression to „Original Sin" and as put forward by Eichengreen und Hausmann (1999). Countries such Japan, Switzerland and China are virtuous because of their high saving rates. The resulting current account surpluses and rising foreigncurrency denominated international creditor positions create, however, the curse of persistent appreciation pressure and foreign exchange risk.

15 What can be regarded as a mercantilist trade strategy. See for instance Dooley et al. (2004).

16 In the portfolio balance model by Branson (1977) investors have a preference for domestic assets in face of exchange rate uncertainty, and hold foreign assets only for a risk mark-up. The portfolio balance model can also explain why - as in the case of Japan - the currency of a country with a persistently positive current account balance follows an appreciation trend: An (expansionary) monetary policy shock causes the domestic interest rate to depreciate beyond the long-term 
risk premium $\varphi$ on the domestic interest, which can explain the divergence from the uncovered interest rate parity:

$i_{j}=i_{k}+E\left(\widehat{e_{h l}}\right)+\varphi$

In equation (2) the interest rates of the large reference economies $i_{k}$ - United States and euro area (Germany) - are assumed to be exogenous, because monetary policy decisions are made independently with respect to domestic inflation (and growth). ${ }^{17}$ The domestic interest rates $i_{j}$ of Japan and Switzerland are determined endogenously dependent on interest rate decisions in large industrial countries and on expected (percent) exchange rate changes $\mathrm{E}\left(\hat{\mathrm{e}}_{\mathrm{hl}}\right)$. If, due to large foreign-currency denominated assets, the exchange rate is expected to appreciate, the risk premium will be negative thereby further depressing the domestic interest rate.

\section{Data and Estimation Framework}

Up to the present few empirical research has scrutinized a negative risk premium on interest rates of international creditor countries. Therefore, we perform such a test for Japan, Switzerland and a group of European reference countries assuming that Germany has been traditionally in the core of the European system of exchange rate stabilization. The US is used as the anchor country for Japan.

We collect data for Japan and Switzerland, as well as for a set of EU member states also including Iceland and Norway as a reference group, which implies a total of 29 countries in the sample. ${ }^{18}$ Nine East Asian countries as reference group for Japan were removed from the sample due to their extensive capital controls, which have increasingly disturbed the open interest rate parity condition. In order to derive policy recommendations for Switzerland, the EU member states provide an adequate reference

equilibrium, which implies a continuous appreciation path along with a positive current account position.

17 See Calvo and Reinhart (2002) for this asymmetry of the world monetary system.

18 Austria, Belgium, Bosnia-Herzegovina, Bulgaria, Croatia, Czech Republic, Denmark, Estonia, Finland, France, Hungary, Iceland, Ireland, Italy, Japan, Latvia, Lithuania, Luxemburg, Netherlands, Norway, Poland, Portugal, Romania, Slovak Republic, Slovenia, Spain, Sweden, Switzerland and United Kingdom. 
group because monetary shocks originating in the euro area / Germany are the same and full capital mobility can be assumed due to the institutional framework of the European Union (Single Market). The observation period starts in 1980, when international capital markets among industrial countries had become widely liberalized. For the central and eastern European countries the data start 1995 due to data availability. This implies an unbalanced panel. See Table 1 for a detailed data description.

Table 1: Data Description

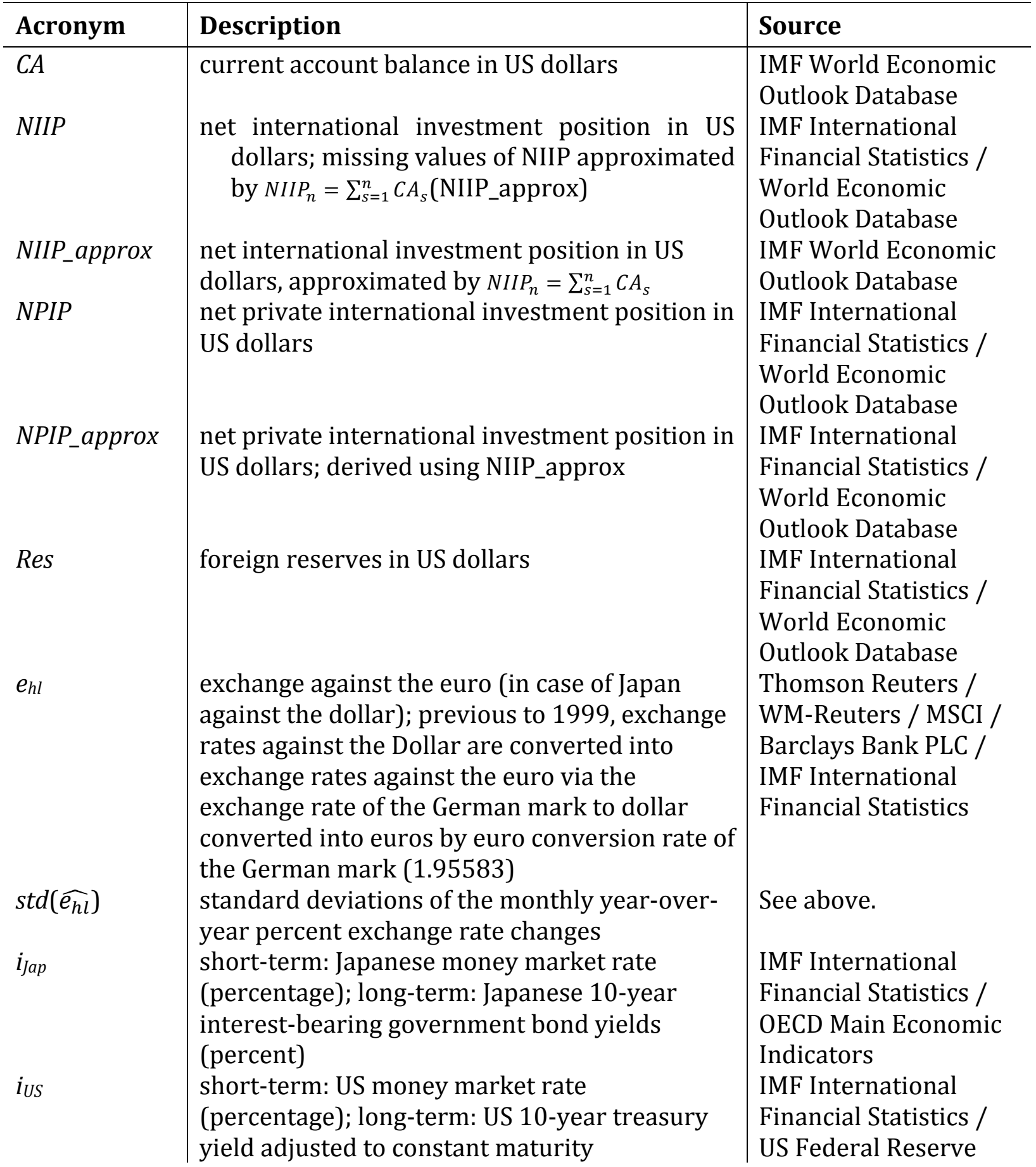




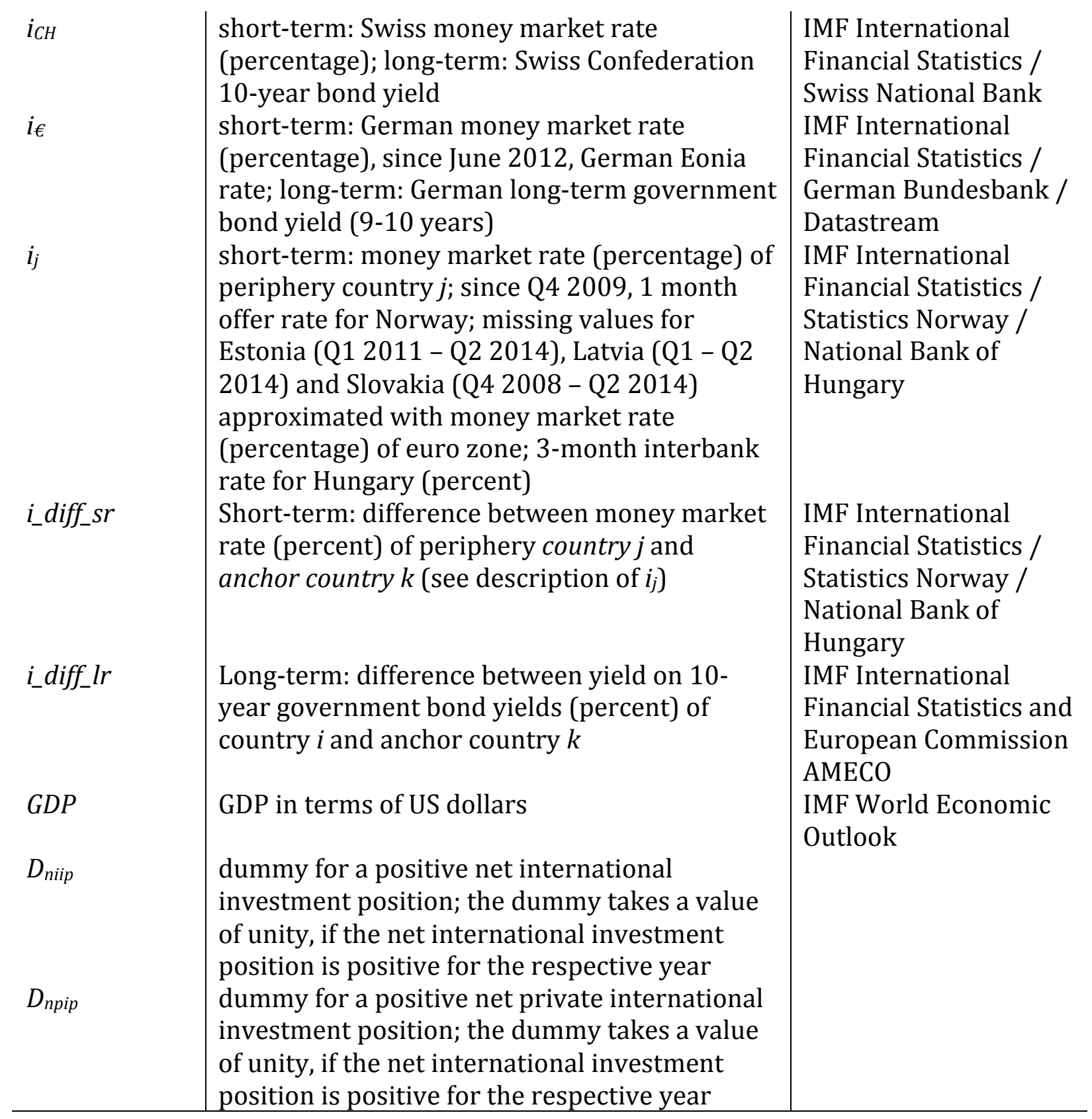

The theory of a negative risk premium on the interest rate of the creditor economies assumes that the net international investment positions and exchange rate uncertainty are important determinants of the risk premium. Interest rates are defined as overnight money market rates (short-term) as well as ten-year government bond yields (longterm) in percent per annum to cover different maturities (see also Figure 1). Exchange rate data are drawn from IMF International Financial Statistics. Exchange rate changes are calculated as monthly year-over-year percent changes of the domestic currency versus the anchor currency (dollar, euro) in price notion multiplied by 100. A proxy for 
exchange rate uncertainty is compiled based on the standard deviations of the monthly year-over-year exchange rate changes of the underlying year.

Net international investment positions (NIIP) are provided by the IMF World Economic Outlook. If data are not available, accumulated current account positions (CA) are used instead. The starting point is 1980 for all western and southern European countries and 1995 for all central and eastern European economies. As an alternative measure net international investment positions are approximated by the accumulated current account positions since 1980 (or 1995 respectively). Net foreign reserves (Res) are used as a proxy for public net international investment positions. By subtracting net foreign reserves from overall net international investment positions we compile private net international investment positions (NPIP). Net overall international investment positions, net private international investment positions, and foreign reserves in dollars are normalized by dollar GDP. ${ }^{19}$ For these variables lower case letters indicate ratios by GDP.

Given the very strong inertia in current account positions and therefore in net foreign asset / liability positions (Lane and Milesi-Ferretti 2007), we assume long-term exchange rate expectations to be persistent as well. Table 2 depicts five-year period averages (which implies seven sub-periods) of all open interest rate parity components for Japan and Switzerland for the observation period from 1980 to 2015. This enables us to capture long-term trends in expectation building and to eliminate the impact of cyclical exchange rate fluctuations in the underlying time series.

For both, Japan (with respect to the US) and Switzerland (with respect to Germany/euro area), the interest rate differential is negative for all except one sub-periods and the overall observation period. In addition, the long-term exchange rate trends for currencies show an appreciation trend, which is line with the open interest rate parity. Nevertheless, in some sub-periods the Japanese yen and the Swiss franc have depreciated against the dollar and the German mark/euro, respectively. This contradicts open interest rate parity. For the whole observation period, exchange rate volatility and the negative risk premium are larger for Japan than for Switzerland.

19 Lane and Milesi-Feretti (2001) use nominal exports for normalization. They argue that normalizing by GDP or alternatively by exports does not significantly change the econometric estimation results. 
Table 2: Components of Augmented UIP for Japan and Switzerland

\begin{tabular}{|c|c|c|c|c|c|c|c|c|}
\hline & Japan & & & & Switze & nd & & \\
\hline short & $i_{J a p}-i_{U S}$ & $\hat{e}_{Y e n / \$}$ & $\varphi$ & $\operatorname{std}\left(\hat{e}_{Y e n / \$}\right)$ & $i_{C H}-i_{\epsilon}$ & $\hat{e}_{C H F / €}$ & $\varphi$ & $\operatorname{std}\left(\hat{e}_{C H F / €)}\right)$ \\
\hline $80-84$ & $-4,70$ & 2,03 & $-6,73$ & 9,94 & $-5,63$ & $-3,94$ & $-1,79$ & 5,98 \\
\hline $85-89$ & $-2,85$ & $-9,20$ & 6,36 & 14,40 & $-1,93$ & $-0,43$ & $-1,42$ & 3,81 \\
\hline $90-94$ & 0,06 & $-5,52$ & 5,58 & 7,99 & $-1,29$ & $-2,00$ & 0,60 & 4,47 \\
\hline $95-99$ & $-4,86$ & 3,08 & $-7,95$ & 13,93 & $-1,85$ & $-0,18$ & $-1,68$ & 4,31 \\
\hline 00-04 & $-2,82$ & $-0,61$ & $-2,21$ & 9,47 & $-1,82$ & $-0,66$ & $-1,17$ & 3,65 \\
\hline 05-09 & $-2,82$ & $-2,45$ & $-0,37$ & 8,55 & $-1,50$ & $-0,35$ & $-1,08$ & 3,91 \\
\hline $10-14$ & $-0,04$ & 3,11 & $-3,15$ & 12,27 & $-0,37$ & $-4,10$ & 3,67 & 5,68 \\
\hline 80-15 & $-2,58$ & $-1,37$ & $-1,21$ & 11,93 & $-2,06$ & $-1,65$ & $-0,41$ & 4,93 \\
\hline long & $i_{\text {Jap }}-i_{U S}$ & $\hat{e}_{Y e n / \$}$ & $\varphi$ & $\operatorname{std}\left(\hat{e}_{Y e n / \$}\right)$ & $i_{C H}-i_{\epsilon}$ & $\hat{e}_{C H F / \epsilon}$ & $\varphi$ & $\operatorname{std}\left(\hat{e}_{C H F / €)}\right)$ \\
\hline $80-84$ & $-4,27$ & 2,03 & $-6,30$ & 9,94 & $-3,97$ & $-3,94$ & $-0,03$ & 5,98 \\
\hline $85-89$ & $-3,67$ & $-9,20$ & 5,53 & 14,40 & $-2,03$ & $-0,43$ & $-1,60$ & 3,81 \\
\hline $90-94$ & $-1,86$ & $-5,52$ & 3,66 & 7,99 & $-1,89$ & $-2,00$ & 0,11 & 4,47 \\
\hline $95-99$ & $-3,67$ & 3,08 & $-6,76$ & 13,93 & $-1,77$ & $-0,18$ & $-1,59$ & 4,31 \\
\hline 00-04 & $-3,42$ & $-0,61$ & $-2,81$ & 9,47 & $-1,42$ & $-0,66$ & $-0,76$ & 3,65 \\
\hline 05-09 & $-2,61$ & $-2,45$ & $-0,16$ & 8,55 & $-1,20$ & $-0,35$ & $-0,85$ & 3,91 \\
\hline $10-14$ & $-1,66$ & 3,11 & $-4,77$ & 12,27 & $-0,89$ & $-4,10$ & 3,21 & 5,68 \\
\hline $80-14$ & $-3,03$ & $-1,37$ & $-1,66$ & 11,93 & $-1,88$ & $-1,67$ & $-0,22$ & 4,86 \\
\hline
\end{tabular}

Source: Datastream. German mark / Germany represents the euro / euro area before January 1999. Exchange rate changes calculated as year-over-year monthly percent changes of the yen against the dollar and the Swiss franc against the euro / German mark.

The descriptive statistics for the overall sample after removing outliers are shown in Table 3. Net international investment positions range from $-700 \%$ of GDP to $224 \%$ of GDP with a mean of $-13 \%$ of GDP. The approximation of net international investment positions by accumulated past current account balances exhibit a substantially lower average level at $-7 \%$ of GDP, which provides evidence in favour of substantial revaluation effects. Private net international investment positions have on average more negative values than overall net international investment positions (-24\% of GDP). This is caused by the asymmetry in the international monetary system, where periphery 
central banks hold large amounts of foreign reserves (on average an equivalent of $10 \%$ of GDP in our sample). This implies that to a certain degree rising private net international debtor positions are counterbalanced by positive public net international investment positions. The descriptive statistics also reveal a very high degree of exchange rate variability over time and across the country dimension.

Table 3: Descriptive Statistics

\begin{tabular}{|c|c|c|c|c|c|c|}
\hline Variable & & Mean & Std. Dev. & Min & Max & Observations \\
\hline \multirow{3}{*}{ i_diff_sr } & overall & 3.10 & 8.70 & -8.95 & 116.61 & 820 \\
\hline & between & & 5.33 & -2.58 & 26.45 & $\mathrm{n}=$ \\
\hline & within & & 7.35 & -21.27 & 108.42 & T-bar $=28.28$ \\
\hline \multirow[t]{3}{*}{ i_diff_lr } & overall & 1.56 & 3.07 & -4.54 & 42.91 & $\mathrm{~N}=733$ \\
\hline & between & & 1.69 & -2.11 & 4.64 & $\mathrm{n}=$ \\
\hline & within & & 2.55 & -2.77 & 39.83 & T-bar $=26.18$ \\
\hline \multirow[t]{3}{*}{ phi_sr } & overall & 1.30 & 5.65 & -32.34 & 27.25 & $\mathrm{~N}=793$ \\
\hline & between & & 1.67 & -1.86 & 5.46 & $\mathrm{n}=$ \\
\hline & within & & 5.45 & -32.44 & 30.42 & T-bar $=27.34$ \\
\hline \multirow[t]{3}{*}{ phi_lr } & overall & 0.65 & 5.47 & -44.28 & 28.15 & $\mathrm{~N}=733$ \\
\hline & between & & 1.63 & -4.27 & 4.52 & $\mathrm{n}=$ \\
\hline & within & & 5.28 & -39.36 & 30.20 & T-bar $=26.18$ \\
\hline \multirow[t]{3}{*}{ niip } & overall & -0.13 & 0.76 & -7.01 & 2.24 & $\mathrm{~N}=817$ \\
\hline & between & & 0.57 & -1.53 & 1.29 & $\mathrm{n}=$ \\
\hline & within & & 0.49 & -5.61 & 1.06 & T-bar $=28.17$ \\
\hline \multirow[t]{3}{*}{ niip_approx } & overall & -0.07 & 0.45 & -1.75 & 1.42 & $\mathrm{~N}=817$ \\
\hline & between & & 0.38 & -0.67 & 0.70 & $\mathrm{n}=$ \\
\hline & within & & 0.26 & -1.25 & 0.87 & T-bar $=28.17$ \\
\hline \multirow[t]{3}{*}{ npip } & overall & -0.24 & 0.77 & -7.31 & 2.24 & $\mathrm{~N}=818$ \\
\hline & between & & 0.59 & -1.64 & 1.24 & $\mathrm{n}=29$ \\
\hline & within & & 0.51 & -5.91 & 1.02 & T-bar $=28.21$ \\
\hline \multirow[t]{3}{*}{ npip_approx } & overall & -0.17 & 0.48 & -2.19 & 1.30 & $\mathrm{~N}=817$ \\
\hline & between & & 0.42 & -0.89 & 0.68 & $\mathrm{n}=29$ \\
\hline & within & & 0.27 & -1.68 & 0.78 & T-bar $=28.17$ \\
\hline \multirow[t]{3}{*}{ res } & overall & 0.10 & 0.10 & 0.00 & 0.75 & 827 \\
\hline & between & & 0.07 & 0.00 & 0.27 & $\mathrm{n}=29$ \\
\hline & within & & 0.07 & -0.12 & 0.65 & T-bar $=28.52$ \\
\hline \multirow[t]{3}{*}{ e_change } & overall & 1.60 & 7.95 & -29.10 & 93.45 & $\mathrm{~N}=818$ \\
\hline & between & & 3.44 & -1.44 & 13.23 & $\mathrm{n}=29$ \\
\hline & within & & 7.24 & -26.78 & 81.82 & T-bar $=28.21$ \\
\hline \multirow[t]{3}{*}{ sigma } & overall & 2.52 & 3.07 & 0.00 & 32.37 & $\mathrm{~N}=814$ \\
\hline & between & & 1.94 & 0.18 & 8.54 & $\mathrm{n}=29$ \\
\hline & within & & 2.34 & -4.62 & 26.34 & T-bar $=28.07$ \\
\hline
\end{tabular}


We perform panel unit root tests for unbalanced panels to test for non-stationarity in all panels. The Fisher-type unit root tests are well suited for our data for two reasons. First, these tests allow the autoregressive parameter to be panel specific. Second, as the Fisher tests perform a unit root test for each panel, they also account for country heterogeneity. We use the ADF-type-test in order to be able to include a drift parameter, since the mean of each variable for each country is non-zero. We also use 3 lags and remove crosssectional means. In all cases the null hypothesis (all panels contain unit roots) is rejected at high levels of significance (against the alternative that at least one panel is stationary). The results do not change with varying lag-lengths.

We follow Milesi-Ferretti (2001) by tracing the impact of the net foreign asset positions on interest rate differentials $\left(\mathrm{i}_{\mathrm{j}}-\mathrm{i}_{\mathrm{k}}\right)$ between the periphery countries in the Europe and the anchor country as formulated in equation (2). In contrast to Milesi-Feretti (2001) we use nominal interest rates on the left hand-side of the equation instead of real rates. Assuming that purchasing power parity holds, controlling for nominal exchange rate changes on the right hand-side of the equation delivers a similar approach. To see this, combine the augmented interest parity relationship (see equation 2 ) with the relative purchasing power parity $\left(\left(\widehat{e_{h l}}\right)=\hat{p}_{j}-\hat{p}_{k}\right.$, where $\hat{p}_{j}$ is domestic inflation rate and $\hat{p}_{k}$ is the inflation in the anchor country). Fisher parity relates the real interest rate $r$ to the nominal interest rate minus expected inflation: $r_{j}=i_{j}-\hat{p}_{j}$. Therefore, the real interest differential equals $\varphi$ (instead of zero in case of a perfect substitutability of domestic and foreign assets).

$r_{j}-r_{k}=\left(i_{j}-\hat{p}_{j}\right)-\left(i_{k}-\hat{p}_{k}\right)=\left(i_{j}-i_{k}\right)-\left(\widehat{e_{h l}}\right)=\varphi$

To identify the determinants of a possible risk premium on domestic interest we estimate equation (2) with the nominal interest rate differential as regressand. The model is shown in equation (4). As regressors we include exchange rate changes versus the anchor currency $\left(\widehat{e_{h l}}\right)$ (coefficient $\beta_{1}$ ) as well as the two possible determinants of a negative interest rate premium. First, the net foreign asset position niip and alternatively the net private international investment position (coefficient $\beta_{2}$ ): a negative sign is expected with a positive (negative) net international investment 
position being linked to a more negative (positive) interest rate differential as found by Lane and Milesi-Feretti (2001).

Second, exchange rate uncertainty is assumed to come along with a more negative interest rate differential. This term is an extension of Milesi-Feretti (2001) reflecting the theory of a negative interest rate premium. Our measure of exchange rate uncertainty (standard deviation of percent exchange rate changes against the anchor currency) always takes a positive value. Therefore, we aim to disentangle the effect for countries with positive net international investment positions by using a dummy that takes the value of 1 for countries with a positive private net international investment position and zero otherwise (negative private net international investment position).

This implies that the coefficient $\beta_{3}$ captures the impact of exchange uncertainty on the interest rate differential of periphery countries with negative net (private) foreign asset positions. The coefficient $\beta_{4}$ captures the difference for countries with positive net foreign asset positions. The sum of both coefficients $\left(\beta_{3}+\beta_{4}\right)$ captures the overall impact of exchange rate uncertainty on the interest rate differential for countries with positive net foreign asset positions. The estimations are made for short-term interest rate differentials (short-term money markets rates) as well as long-term interest rate differentials (10year government bonds yields). The Hausman test suggests a fixed effects model to control for country-specific time invariant effects in the estimation. We also control for time-fixed effects by adding time dummies. This delivers the following estimation equation:

$$
i_{j}-i_{k}=\alpha_{i}+\beta_{1} \hat{e}_{h l}+\beta_{2} \frac{N P I P_{i t}}{G D P_{i t}}+\beta_{3} \operatorname{std}(\hat{e})_{i t}+\beta_{4} \operatorname{std}(\hat{e})_{i t} * D_{N P I P}+\epsilon_{i t}
$$

\section{Estimation Results}

Table 4 and Table 5 report the estimation results for short-term interest rate differentials (i.e. based on money market rates). Models (1) to (4) capture the contemporaneous effects for the net international investment positions, which are proxied either by the overall net foreign investment positions or the net private international investment position. For both overall net international investment 
positions and net private international investment positions the coefficient is positive. The coefficients are statistically significantly at the common levels, but do not have the expected sign. This implies that positive net international investment position are linked to higher domestic interest rates. That is the opposed result to the OECD country sample of Lane and Milesi-Feretti (2001).

Table 4: OLS Estimation Results - Short-run Interest Rate Differential

\begin{tabular}{|c|c|c|c|c|}
\hline i_diff_sr & Model (1) & Model (2) & Model (3) & Model (4) \\
\hline niip & $\begin{array}{l}1.24^{* *} \\
(0.59)\end{array}$ & & & \\
\hline \multicolumn{5}{|l|}{ niip_approx } \\
\hline l.niip & & & $\begin{array}{l}1.28^{* *} \\
(0.49)\end{array}$ & \\
\hline \multicolumn{5}{|l|}{ l.niip_approx } \\
\hline npip & & $\begin{array}{l}1.14^{*} \\
(0.59)\end{array}$ & & \\
\hline \multicolumn{5}{|l|}{ npip_approx } \\
\hline l.npip & & & & $\begin{array}{l}1.23^{* *} \\
(0.51)\end{array}$ \\
\hline \multicolumn{5}{|l|}{ l.npip_approx } \\
\hline e_change & $\begin{array}{l}0.31^{* *} \\
(0.14)\end{array}$ & $\begin{array}{l}0.31^{* *} \\
(0.14)\end{array}$ & & \\
\hline l.e_change & & & $\begin{array}{c}0.23^{* * *} \\
(0.08)\end{array}$ & $\begin{array}{c}0.23^{* * *} \\
(0.08)\end{array}$ \\
\hline sigma & $\begin{array}{c}0.21^{*} \\
(0.12)\end{array}$ & $\begin{array}{c}0.17^{*} \\
(0.09)\end{array}$ & $\begin{array}{l}0.38^{* *} \\
(0.18)\end{array}$ & $\begin{array}{c}0.36^{*} \\
(0.18)\end{array}$ \\
\hline niip_sigma & $\begin{array}{c}-0.59 * * * \\
(0.21)\end{array}$ & & $\begin{array}{c}-0.57^{* *} \\
(0.22)\end{array}$ & \\
\hline \multicolumn{5}{|c|}{ niip_approx_sigma } \\
\hline npip_sigma & & $\begin{array}{c}-0.46^{* *} \\
(0.17)\end{array}$ & & $\begin{array}{c}-0.48^{* *} \\
(0.19)\end{array}$ \\
\hline \multicolumn{5}{|c|}{ npip_approx_sigma } \\
\hline Constant & $\begin{array}{c}5.10^{* * *} \\
(1.23)\end{array}$ & $\begin{array}{c}5.09 * * * \\
(1.21)\end{array}$ & $\begin{array}{c}1.31 \\
(1.10)\end{array}$ & $\begin{array}{c}3.91^{* * *} \\
(1.54)\end{array}$ \\
\hline $\begin{array}{c}\beta_{3}+\beta_{4} \\
{[\text { Prob }>\text { F }]}\end{array}$ & $\begin{array}{c}-0.38 * * \\
{[0.0284]}\end{array}$ & $\begin{array}{c}-0.29 * * \\
{[0.0305]}\end{array}$ & $\begin{array}{c}-0.19^{* *} \\
{[0.0432]}\end{array}$ & $\begin{array}{c}-0.12^{* *} \\
{[0.0477]}\end{array}$ \\
\hline Observations & 790 & 791 & 766 & 767 \\
\hline \multicolumn{5}{|l|}{ R-squared } \\
\hline Within & 0.4489 & 0.4399 & 0.4019 & 0.3952 \\
\hline Between & 0.3010 & 0.2322 & 0.3722 & 0.3040 \\
\hline Overall & 0.3794 & 0.3530 & 0.3623 & 0.3405 \\
\hline
\end{tabular}

Note: The dependent variable is i_diff_sr and regressions (1) - (4) include a country fixed effect. Npip and niip (as well as their approximations) are expressed in terms of percentage of GDP. Robust standard errors are reported in parentheses. The significance of coefficients is reported at the $10 \%, 5 \%$, and $1 \%$ level, indicated by $*, * *, * *$, respectively. The time dummies are not reported for parsimony reasons. They are available on request. 
The exchange term has the expected positive sign: a negative (positive) interest rate differential is associated with an appreciation (depreciation) of the periphery currency as suggested by the open interest rate condition. The coefficients are significant at the $5 \%$ level. The overall effect of exchange rate uncertainty for countries with negative net international investment positions on the nominal interest rate differential is positive. With increasing exchange rate uncertainty the interest rate relative to the anchor country also increases (coefficients: $0.21,0.17,0.38,0.36$ ). For countries with positive net international investment positions this effect is significantly different (coefficients: $0.59,-0.46,-0.57,-0.48)$. This implies a negative risk premium on domestic interest rates of countries with positive net (private) international investment positions linked to exchange rate uncertainty (coefficients: $-0.38,-0.29,-0.19,-0.12$ ). The overall effects for countries with positive net private international investment positions are statistically significant at the five-percent level as implied by the Wald test for joint significance. These results do not change if the (private) international investment position and exchange rate changes are lagged to control for possible endogeneity. ${ }^{20}$

Table 5 provides the estimation results for the case of substituting net (private) international investment positions (as officially reported by the IMF and/or national monetary authorities) by accumulated current account positions. These proxies exclude valuations effects on net foreign asset positions, which can be substantial as shown by Bénétrix et al. (2014). Nevertheless they are included as a robustness test. The results do not change qualitatively.

20 We do not assume a systematic impact of the interest rate differential on exchange rate uncertainty. 
Table 5: OLS Estimation Results - Short-run Interest Rate Differential (cont.)

\begin{tabular}{|c|c|c|c|c|}
\hline i_diff_sr & Model (5) & Model (6) & Model (7) & Model (8) \\
\hline \multicolumn{5}{|l|}{ niip } \\
\hline niip_approx & $\begin{array}{c}3.84^{* * *} \\
(1.06)\end{array}$ & & & \\
\hline \multicolumn{5}{|l|}{ l.niip } \\
\hline l.niip_approx & & & $\begin{array}{c}3.89 * * * \\
(0.97)\end{array}$ & \\
\hline \multicolumn{5}{|l|}{ npip } \\
\hline npip_approx & & $\begin{array}{c}3.80^{* * *} \\
(1.23)\end{array}$ & & \\
\hline \multicolumn{5}{|l|}{ l.npip } \\
\hline l.npip_approx & & & & $\begin{array}{c}3.86^{* * *} \\
(1.19)\end{array}$ \\
\hline e_change & $\begin{array}{l}0.30^{* *} \\
(0.14)\end{array}$ & $\begin{array}{l}0.30^{* *} \\
(0.14)\end{array}$ & & \\
\hline l.e_change & & & $\begin{array}{l}0.22^{* *} \\
(0.08)\end{array}$ & $\begin{array}{c}0.22^{* * *} \\
(0.08)\end{array}$ \\
\hline sigma & $\begin{array}{c}0.14^{*} \\
(0.08)\end{array}$ & $\begin{array}{c}0.13 \\
(0.08) \\
\end{array}$ & $\begin{array}{l}0.36^{* *} \\
(0.18) \\
\end{array}$ & $\begin{array}{c}0.33^{*} \\
(0.17)\end{array}$ \\
\hline \multicolumn{5}{|l|}{ niip_sigma } \\
\hline niip_approx_sigma & $\begin{array}{c}-0.37 * * * \\
(0.12) \\
\end{array}$ & & $\begin{array}{c}-0.45^{* * *} \\
(0.16) \\
\end{array}$ & \\
\hline \multicolumn{5}{|l|}{ npip_sigma } \\
\hline npip_approx_sigma & & $\begin{array}{c}-0.36^{* * *} \\
(0.12) \\
\end{array}$ & & $\begin{array}{c}-0.39 * * * \\
(0.14) \\
\end{array}$ \\
\hline Constant & $\begin{array}{c}5.82^{* * *} \\
(1.12) \\
\end{array}$ & $\begin{array}{c}6.04^{* * *} \\
(1.09) \\
\end{array}$ & $\begin{array}{c}5.55^{* * *} \\
(0.80) \\
\end{array}$ & $\begin{array}{c}4.17^{* * *} \\
(1.20) \\
\end{array}$ \\
\hline $\begin{array}{c}\beta_{3}+\beta_{4} \\
{[\text { Prob }>\text { F }]}\end{array}$ & $\begin{array}{c}-0.23^{* *} \\
{[0.0124]}\end{array}$ & $\begin{array}{c}-0.23^{* *} \\
{[0.0143]}\end{array}$ & $\begin{array}{c}-0.09 * * \\
{[0.0253]}\end{array}$ & $\begin{array}{c}-0.06^{* *} \\
{[0.0290]}\end{array}$ \\
\hline Observations & 790 & 790 & 766 & 766 \\
\hline \multicolumn{5}{|l|}{ R-squared } \\
\hline Within & 0.4660 & 0.4623 & 0.4226 & 0.4166 \\
\hline Between & 0.0036 & 0.0004 & 0.0282 & 0.0095 \\
\hline Overall & 0.2205 & 0.1986 & 0.2264 & 0.1925 \\
\hline
\end{tabular}

Note: The dependent variable is i_diff_sr and regressions (5) - (8) include a country fixed effect. Npip and niip (as well as their approximations) are expressed in terms of percentage of GDP. Robust standard errors are reported in parentheses. The significance of coefficients is reported at the $10 \%, 5 \%$, and $1 \%$ level, indicated by $*, * *, * *$, respectively. The time dummies are not reported for parsimony reasons. They are available on request.

Tables 6 and 7 report the estimation results for long-term interest rate differentials calculated based on ten-year government bond yields. The signs of net foreign asset positions remain positive but turn insignificant. There is evidence that the negative (positive) nominal long-term interest rate differentials are associated with an appreciating (depreciation) domestic currency, albeit the effect is smaller compared to 
short-term interest differentials. The results for the impact of exchange rate uncertainty on the interest rate differential versus the anchor country remain widely unchanged.

Table 6: OLS Estimation Results - Long-run Interest Rate Differential

\begin{tabular}{|c|c|c|c|c|}
\hline i_diff_lr & Model (1) & Model (2) & Model (3) & Model (4) \\
\hline niip & $\begin{array}{c}0.28 \\
(0.28)\end{array}$ & & & \\
\hline \multicolumn{5}{|l|}{ niip_approx } \\
\hline l.niip & & & $\begin{array}{c}0.27 \\
(0.25)\end{array}$ & \\
\hline \multicolumn{5}{|l|}{ l.niip_approx } \\
\hline npip & & $\begin{array}{c}0.20 \\
(0.24)\end{array}$ & & \\
\hline \multicolumn{5}{|l|}{ npip_approx } \\
\hline l.npip & & & & $\begin{array}{c}0.22 \\
(0.22)\end{array}$ \\
\hline \multicolumn{5}{|l|}{ l.npip_approx } \\
\hline e_change & $\begin{array}{l}0.06^{* *} \\
(0.02)\end{array}$ & $\begin{array}{l}0.06^{* *} \\
(0.02)\end{array}$ & & \\
\hline l.e_change & & & $\begin{array}{c}0.07^{* * *} \\
(0.03)\end{array}$ & $\begin{array}{c}0.07^{* * *} \\
(0.02)\end{array}$ \\
\hline sigma & $\begin{array}{c}0.10^{*} \\
(0.06) \\
\end{array}$ & $\begin{array}{c}0.08 \\
(0.05) \\
\end{array}$ & $\begin{array}{c}0.10^{*} \\
(0.05)\end{array}$ & $\begin{array}{c}0.10^{*} \\
(0.05)\end{array}$ \\
\hline niip_sigma & $\begin{array}{l}-0.23^{*} \\
(0.12) \\
\end{array}$ & & $\begin{array}{c}-0.24^{* *} \\
(0.11)\end{array}$ & \\
\hline \multicolumn{5}{|c|}{ niip_approx_sigma } \\
\hline npip_sigma & & $\begin{array}{l}-0.22^{*} \\
(0.12) \\
\end{array}$ & & $\begin{array}{l}-0.24^{*} \\
(0.12) \\
\end{array}$ \\
\hline \multicolumn{5}{|c|}{ npip_approx_sigma } \\
\hline Constant & $\begin{array}{c}4.33^{* * *} \\
(0.67)\end{array}$ & $\begin{array}{c}4.17^{* * *} \\
(0.69)\end{array}$ & $\begin{array}{c}4.19 * * * \\
(0.68)\end{array}$ & $\begin{array}{c}5.17^{* * *} \\
(0.76)\end{array}$ \\
\hline $\begin{array}{c}\beta_{3}+\beta_{4} \\
{[\text { Prob }>\text { F }]}\end{array}$ & $\begin{array}{c}-0.13^{*} \\
{[0.0822]}\end{array}$ & $\begin{array}{c}-0.13 \\
{[0.1036]}\end{array}$ & $\begin{array}{c}-0.14^{* *} \\
{[0.0497]}\end{array}$ & $\begin{array}{c}-0.14^{*} \\
{[0.0607]}\end{array}$ \\
\hline Observations & 716 & 717 & 700 & 701 \\
\hline \multicolumn{5}{|l|}{ R-squared } \\
\hline Within & 0.5550 & 0.5522 & 0.5608 & 0.5590 \\
\hline Between & 0.0071 & 0.0064 & 0.0026 & 0.0025 \\
\hline Overall & 0.3205 & 0.3212 & 0.3365 & 0.3364 \\
\hline
\end{tabular}

Note: The dependent variable is i_diff_lr and regressions (1) - (4) include a country fixed effect. Owing to the lack of long-term interest rate data, Bosnia and Herzegovina is now excluded from the sample. Npip and niip (as well as their approximations) are expressed in terms of percentage of GDP. Robust standard errors are reported in parentheses. The significance of coefficients is reported at the $10 \%, 5 \%$, and $1 \%$ level, indicated by $*, * *, * * *$, respectively. The time dummies are not reported for parsimony reasons. They are available on request. 
Table 7: OLS Estimation Results - Long-run Interest Rate Differential (cont.)

\begin{tabular}{|c|c|c|c|c|}
\hline i_diff_lr & Model (5) & Model (6) & Model (7) & Model (8) \\
\hline \multicolumn{5}{|l|}{ niip } \\
\hline niip_approx & $\begin{array}{c}1.19 \\
(0.75)\end{array}$ & & & \\
\hline \multicolumn{5}{|l|}{ l.niip } \\
\hline l.niip_approx & & & $\begin{array}{c}1.16 \\
(0.70)\end{array}$ & \\
\hline \multicolumn{5}{|l|}{ npip } \\
\hline npip_approx & & $\begin{array}{c}0.94 \\
(0.75)\end{array}$ & & \\
\hline \multicolumn{5}{|l|}{ l.npip } \\
\hline l.npip_approx & & & & $\begin{array}{c}1.02 \\
(0.74)\end{array}$ \\
\hline e_change & $\begin{array}{l}0.06^{* *} \\
(0.02)\end{array}$ & $\begin{array}{l}0.06^{* *} \\
(0.02)\end{array}$ & & \\
\hline l.e_change & & & $\begin{array}{c}0.07^{* * *} \\
(0.02)\end{array}$ & $\begin{array}{c}0.07^{* * *} \\
(0.02)\end{array}$ \\
\hline sigma & $\begin{array}{l}0.09^{* *} \\
(0.04)\end{array}$ & $\begin{array}{c}0.07 \\
(0.04)\end{array}$ & $\begin{array}{l}0.11^{* *} \\
(0.04) \\
\end{array}$ & $\begin{array}{c}0.08^{*} \\
(0.04)\end{array}$ \\
\hline \multicolumn{5}{|l|}{ niip_sigma } \\
\hline niip_approx_sigma & $\begin{array}{c}-0.20^{* *} \\
(0.10)\end{array}$ & & $\begin{array}{l}-0.22^{*} \\
(0.11)\end{array}$ & \\
\hline \multicolumn{5}{|l|}{ npip_sigma } \\
\hline npip_approx_sigma & & $\begin{array}{c}-0.12^{* *} \\
(0.04)\end{array}$ & & $\begin{array}{c}-0.13^{* * *} \\
(0.04) \\
\end{array}$ \\
\hline Constant & $\begin{array}{c}4.69^{* * *} \\
(0.55)\end{array}$ & $\begin{array}{c}4.20^{* * *} \\
(0.62)\end{array}$ & $\begin{array}{c}4.45^{* * *} \\
(0.43)\end{array}$ & $\begin{array}{c}5.13^{* * *} \\
(0.73)\end{array}$ \\
\hline $\begin{array}{c}\beta_{3}+\beta_{4} \\
{[\text { Prob }>\text { F }]}\end{array}$ & $\begin{array}{c}-0.11^{* *} \\
{[0.0234]}\end{array}$ & $\begin{array}{c}-0.05^{* *} \\
{[0.0355]}\end{array}$ & $\begin{array}{c}-0.11^{* *} \\
{[0.0291]}\end{array}$ & $\begin{array}{l}-0.05^{* * *} \\
{[0.0061]}\end{array}$ \\
\hline Observations & 716 & 716 & 700 & 700 \\
\hline \multicolumn{5}{|l|}{ R-squared } \\
\hline Within & 0.5651 & 0.5500 & 0.5701 & 0.5566 \\
\hline Between & 0.1283 & 0.1298 & 0.1197 & 0.1381 \\
\hline Overall & 0.2027 & 0.1903 & 0.2204 & 0.1941 \\
\hline
\end{tabular}

Note: The dependent variable is i_diff_lr and regressions (5) - (8) include a country fixed effect. Owing to the lack of long-term interest rate data, Bosnia and Herzegovina is now excluded from the sample. Npip and niip (as well as their approximations) are expressed in terms of percentage of GDP. Robust standard errors are reported in parentheses. The significance of coefficients is reported at the $10 \%, 5 \%$, and $1 \%$ level, indicated by $* * *, * * *$, respectively. The time dummies are not reported for parsimony reasons. They are available on request. 
In countries with positive net international investment positions exchange rate uncertainty depresses domestic interest rates. In countries with negative international investment positions domestic interest rate are higher than suggested by exchange rate changes. All in all the econometric estimations deliver mixed evidence for a negative interest rate premium for European countries with positive net international investment positions.

\section{Conclusions}

Based on the case studies of Japan and Switzerland we have established a theory of negative risk premium in countries with (large) foreign currency-denominated assets. It is argued that foreign currency-denominated assets constitute a risk for any individual investor if the future exchange rate is uncertain. To compensate for this risk domestic investors would ask for a mark-up on foreign interest rates. Alternatively, the domestic interest rate has to decline to provide an additional incentive to domestic investors to hold foreign assets (negative risk premium).

Our empirical exercise provides mixed evidence for a negative risk premium on domestic interest rates. The private net international investment positions do not the expected sign. Positive (negative) net international investment positions are associated with a higher (lower) domestic interest rate. However, exchange rate uncertainty seems to matter. Exchange rate uncertainty is linked to a lower domestic interest rate for countries with positive net private international investment positions. Exchange rate uncertainty is positively linked to higher domestic interest rates for countries with private foreign-currency denominated debt at the common levels of statistical significance.

Given that the negative risk premium on domestic interest rates for countries with net private foreign-currency denominated investment positions exist, the negative risk premium can be eliminated if the exchange rate uncertainty is credibly pegged to the anchor country. Given that low interest rates tend fuel exuberance in domestic financial markets, this resulting increase in domestic interest rate can be also seen as a macroprudential tool to safeguard financial stability. The policy recommendations of the findings are, however, subject to further research. 


\section{References:}

Abrahamsen, Yngve / Simmons-Süer, Banu (2011): Die Wechselkursabhängigkeit der Schweizer Wirtschaft. KOF Studien 24, 2011.

Bénétrix, Augustín / Lane, Philip / Shambaugh, Jay (2014): International Currency Exposures, Valuation Effects and the Global Financial Crisis. NBER Working Paper 20820.

Bernholz, Peter / Minsch, Rudolf (2015): Der "Franken-Schock: Die Freigabe des Schweizer Franken - wer gewinnt und wer verliert? ifo Schnelldienst 68, 5, 9-13.

Bordo, Michael / Humpage, Owen / Schwartz, Anna (2012): Epilogue: ForeignExchange-Market Operations in the Twenty-First Century. NBER Working Paper 17984

Branson, William (1977): Exchange Rates in the Short Run: The Dollar Deutsche Mark Rate. European Economic Review 10, 303-24.

Brown, Martin / Peter, Marcel / Wehrmüller, Simon (2009): Swiss Franc Lending in Europe. Mimeo.

Calvo, Guillermo; Reinhart, Carmen (2002): Fear of Floating. Quarterly Journal of Economics 117, 2, 379-408.

Chinn, Menzie (2005): The (Partial) Rehabilitation of Interest Rate Parity in the Floating Rate Era: Longer Horizons, Alternative Expectations, and Emerging Markets" Journal of International Money and Finance 25, 1, 7-21.

Corsetti, Giancarlo / Pesenti, Paolo / Roubini, Nouriel (1999): Paper Tigers?: A Model of the Asian Crisis? European Economic Review 43, 7, 1211-1236.

Danne, Christian / Schnabl, Gunther (2008): A Role Model for China? Exchange Rate Flexibility and Monetary Policy Making in Japan. China Economic Review 19, 2, $183-$ 196.

Dooley, Michael / Folkerts-Landau, David / Garber, Peter (2004): The Revived Bretton Woods System. International Journal of Finance and Economics 9, 4, 307-313.

Eichengreen, Barry / Hausmann, Ricardo (1999): Exchange Rates and Financial Fragility. NBER Working Paper 7418.

Goyal, Rishi and McKinnon, Ronald (2003): Japan's Negative Risk Premium in Interest Rates: The Liquidity Trap and the Fall in Bank Lending. The World Economy 26, 3, 339-363.

Joyce, Joseph (2015): External Balance Sheets as Countercyclical Crisis Buffers. Mimeo.

Kugler, Peter / Weder, Beatrice (2005): Why are Returns of Swiss Franc Assets so Low? Mimeo.

Kugler, Peter / Weder, Beatrice (2009): The Demise of the Swiss Interest Rate Puzzle University of Basle Faculty of Business and Economics Working Paper 2009/04.

Lane, Philip / Milesi-Feretti, Gian Maria (2001): Long-Term Capital Movements. NBER Working Paper 8366.

Lane, Philip / Milesi-Feretti, Gian Maria (2005): A Global Perspective on Net External Positions. IMF Working Paper 05/161. 
Lane, Philip / Milesi-Feretti, Gian Maria (2007): The External Wealth of Nations Mark II: Revised and Extended Estimates of Foreign Assets and Liabilities. Journal of International Economics 73, 2, 223-250.

Lothian, James / Wu, Liuren (2011): Uncovered Interest-Rate Parity over the Past Two Centuries. Journal of International Money and Finance 30, 3, 448-473.

McKinnon, Ronald (2013): The Unloved Dollar Standard: From Bretton Woods to the Rise of China. Oxford University Press.

McKinnon, Ronald / Ohno, Kenichi (1997): Dollar and Yen: Resolving Economic Conflict between the United States and Japan. MIT Press, Cambridge, Massachusetts.

McKinnon, Ronald / Schnabl, Gunther (2004a): The East Asian Dollar Standard, Fear of Floating, and Original Sin. Review of Development Economics 8, 3, 331-360.

McKinnon, Ronald / Schnabl, Gunther (2004b): The Return to Soft Dollar Pegging in East Asia? Mitigating Conflicted Virtue. International Finance 7, 2, 169-201.

McKinnon, Ronald / Schnabl, Gunther (2009): The Case for Stabilizing China's Exchange Rate: Setting the Stage for Fiscal Expansion. China \& World Economy 17, 1-32.

Wu, Jyg-lin / Chen Show-Lin (1998): A Re-Examination of Real Interest Rate Parity. Canadian Journal of Economics 31, 837-851 